\title{
Scanning electron microscopy of the corneal endothelium of ostrich
}

\author{
Microscopia eletrônica de varredura do endotélio da córnea de avestruz
}

\author{
João Antonio Tadeu Pigatto ${ }^{\mathrm{I}}$ Angela Aguiar Franzen ${ }^{\mathrm{II}}$ Fabiana Quartiero Pereira ${ }^{\mathrm{I}}$ \\ Ana Carolina da Veiga Rodarte de AlmeidaI José Luis Laus ${ }^{\text {II }}$ Jaime Maia dos Santos ${ }^{\text {II }}$ \\ Pedro Mancini Guedes ${ }^{\mathrm{III}}$ Paulo Sérgio de Moraes Barros ${ }^{\mathrm{III}}$
}

\section{-NOTE-}

\section{ABSTRACT}

The aim of this study was to examine the endothelial surface morphology and perform a morphometric analysis of the corneal endothelial cells of ostrich (Struthio camelus) using scanning electron microscopy. Polygonality, mean cell area, cell density and coefficient of variation of mean cell area were analyzed. The normal corneal endothelium consisted of polygonal cells of uniform size and shape with few interdigitations of the cell borders. Microvilli appeared as protusions on the cellular surface. The average cell area was $269 \pm 18 \mu^{2}$ and the endothelial cell density was $3717 \pm 240$ cells $\mathrm{mm}^{-2}$. The coefficient of variation of the cell area was 0.06, and the percentage of hexagonal cells was $75 \%$. The parameters evaluated did not differ significantly between the right and the left eye from the same ostrich. The results of this study showed that the ostrich corneal endothelial cells appear quite similar to those of the other vertebrates.

Key words: corneal, endothelium, ostrich, Struthio camelus.

\section{RESUMO}

Objetivou-se examinar a superfície posterior do endotélio corneano e realizar análise morfométrica das células endoteliais da córnea de avestruz (Struthio camelus) valendose da microscopia eletrônica de varredura. Avaliaram-se o número de lados, a área celular média, a densidade celular e o coeficiente de variação da área celular. $O$ endotélio corneano de avestruz constitui-se de células poligonais uniformes em tamanho e forma, e com poucas interdigitações das bordas celulares. Visibilizaram-se microvilosidades na superficie celular.

\begin{abstract}
A área celular média foi de $269 \pm 18 \mu m^{2}$ e a densidade celular foi de $3717 \pm 240$ células $\mathrm{mm}^{-2}$. O coeficiente de variação foi de 0,06 e o percentual de células hexagonais de 75\%. Não foram observadas diferenças significativas entre os parâmetros avaliados entre os olhos esquerdo e direito. Este estudo demonstrou que o endotélio corneano de avestruz é semelhante ao descrito em outros vertebrados.
\end{abstract}

Palavras-chave: endotélio, córnea, avestruz, Struthio camelus.

The corneal endothelium is a single layer of polygonal cells covering the posterior surface of the cornea (TUFT \& COSTER, 1990). The structure of the normal corneal endothelium has been documented in humans (ABIB \& BARRETO, 2001), dogs (GWIN et al., 1982; PIGATTO etal., 2006; RODRIGUES etal., 2006), horses (ANDREW et al., 2001) and other animal species (YEE et al., 1987; COLLIN \& COLLIN, 1998; PIGATTO et al., 2004; PIGATTO et al., 2005a; PIGATTO et al., 2005b). The ostrich (Struthio camelus) is the world's largest living bird. Native of Africa, these flightless bird are important animals in many livestock industries. However, studies about the corneal endothelium of the ostrich (Struthio camelus) have not been reported previously, in the referred literature. The aim of this study was to examine the surface morphology and to

IFaculdade de Veterinária, Universidade Federal do Rio Grande do Sul (UFRGS), CP 15094, 91540-000, Porto Alegre, RS, Brasil. Email: pigatto@ufrgs.br. Autor para correspondência.

"Faculdade de Ciências Agrárias e Veterinárias (FCAV), Universidade Estadual Paulista (UNESP), Campus de Jaboticabal, Jaboticabal, SP, Brasil.

IIIFaculdade de Medicina Veterinária e Zootecnia (FMVZ), Universidade de São Paulo (USP), São Paulo, SP, Brasil. 
perform a morphometric analysis of the normal corneal endothelial cells of ostrich by using scanning electron microscopy (SEM).

These findings help to establish the normal appearance of ostrich corneal endothelial and can be used for comparison with other animal species.

Twenty-four normal eyes from 12 Ostriches (Struthio camelus), males, with 1 year old and about $100 \mathrm{~kg}$ of body weight, were studied. These eyes were obtained from a licensed Brazilian commercial company that breeds ostriches for meat production. All procedures were performed in compliance with the Association for Research in Vision and Ophthalmology statement regarding the use of animals in ophthalmic and vision research. Ostriches were killed in a commercial abattoir, using a standard slaughter protocol. After 1 hour of death, eyes were enucleated and those one that showed evidence of ocular disease were excluded. The posterior endothelial surfaces were examined and photographed using a scanning electron microscope operated at $15 \mathrm{kV}$. Ten photomicrographs were taken from each cornea with magnifications of $\mathrm{X}$ $750, X 1,000$, and X 1,500. The photomicrographs were scanned into the computer, and polygonality was determined. With image analyzer software, the cell area of 100 endothelial cells from each cornea was measured, and mean endothelial cell density was obtained. The coefficient of variation of mean cell area was calculated by dividing the standard deviation of the cell area by mean cell area. Statistical data analysis was conducted using the Tukey test. Values of $\mathrm{P}<0.05$ were considered significant.

The posterior corneal endothelium surface of the ostriches observed on SEM revealed a continuous layer of polygonal cells of uniform size and shape (Figure 1). The cell borders showed few interdigitations. Microvilosities appeared as multiple protusions on cell surface . Cilia were not observed. Small pits were observed scattered over the cell surface. Regarding the polygonality of the endothelium, the majority of cells were six-sided (75\%), with five- (14\%), and seven-sided $(11 \%)$ cells constituting the remaining corneal endothelium. The mean cell area of corneal endothelium was $269 \pm 18 \mu \mathrm{m}^{2}$ and the endothelial cell density was $3717 \pm 240$ cells $\mathrm{mm}^{-2}$. The coefficient of variation of mean cell area was 0.06 . The parameters evaluated did not differ significantly between the right and the left eye from the same Ostrich.

Despite of their considerable use, the effects of preparation of cornea for SEM on corneal endothelium have been described (VIRTANEN et al., 1984). SEM, with appropriate consideration of the effects of fixation, allows the evaluation of morphology and morphometric analysis of endothelial cells of ostrich.

In most vertebrates the shape of normal corneal endothelial cells shows a mosaic-like pattern of polygonal cells (YEE et al., 1987; COLLIN \& COLLIN, 1998; ANDREW et al., 2001; PIGATTO et al., 2004; PIGATTO et al., 2005a; PIGATTO et al., 2006). The pleomorphic characteristics of ostrich corneal endothelium are similar to those of man, cat, dog, and other vertebrates, where $65-80 \%$ of corneal endothelial cells area hexagonal (DOUGHTY, 1989; PIGATTO et al., 2005a). This study shows endothelial cells with minimal variation in size and shape, probably because all animals were of the same age, and only healthy corneas were studied. In other species, endothelial morphologic features and cell densities are dependent on age, with a decrease in endothelial cell density and corresponding increases in cell size and variation in shape with age (GWIN et al., 1982). The coefficient of variation in cell area observed in this study was similar to those described in normal corneal endothelium of other avians (YEE et al., 1987; PIGATTO et al., 2005).

Our results regarding the ultrastructure of the corneal endothelium of ostrich agree with those reported by other authors (YEE et al., 1987; DOUGHTY, 1989; COLLIN \& COLLIN, 1998; PIGATTO et al., 2004; PIGATTO et al., 2005a; PIGATTO et al., 2006). Our study confirmed the presence of microvilli distributed over the surface of each endothelial cell. The small microvilli projected from all the endothelial cells have been described in other vertebrates (COLLIN \& COLLIN, 1998). In the current investigation, we did not detect cilia in the corneal endothelium. However, this structure, protruding into the anterior chamber, was occasionally found in the endothelial cells of humans as well as in other animals (GALLAGHER, 1980). The small pits observed scattered over the cell surface probably represent pinocytotic vesicles, previously documented (SVEDBERGH \& BILL, 1972). Density of corneal endothelial cells using SEM has previously been reported in other species (COLLIN \& COLLIN, 1998; PIGATTO et al., 2004; PIGATTO et al., 2005a; RODRIGUES et al., 2006). The cell densities of the representative species of birds ranged from $4.413 \pm 766$ cells $\mathrm{mm}^{-2}$ to $11.734 \pm 1.687$ cells $\mathrm{mm}^{-2}$ (COLLIN \& COLLIN, 1998). Our results showed that cell density is similar to that found by COLLIN and COLLIN (1998). This study showed that the parameters evaluated did not differ significantly between both eyes from the same ostrich. Such findings are in agreement with previous studies (TUFT \& COSTER, 1990; ANDREW et al., 2001; PIGATTO et al., 2004; PIGATTO et al., 2005b). The ultrastructure and the morphometric parameters of the 




Figure 1 - Scanning electron micrograph of normal corneal endothelium of ostrich, showing polygonal cells of uniform in size and shape. The predominant number of cells are hexagonal. x 750; Bar $=10 \mu \mathrm{m}$.

Ostrich corneal endothelium are similar to those described in other vertebrates. Furthermore, these data will increase our understanding about the environmental constraints placed on the non mammalian cornea and the evolutionary development of this tissue.

\section{REFERENCES}

ABIB, F.C.; BARRETO, J. Behavior of corneal endothelial density over a lifetime. Journal of Cataract \& Refractive Surgery, v.27, n.10, p.1574-1578, 2001. Disponível em: h t t p : / / w w w. s c i e n c e d i r e c t. c o m/ science?_ob=ArticleURL\&_udi=B6VSF-448J975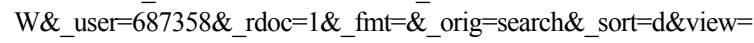 c \&_a c c t $=$ C $000037899 \&$ version $=1 \&$ ur 1 Ve $\mathrm{r}$ s i o n $=0$ \&_ u s e r i d $=6877358$ \& m d5=0071b6cf46a3a9acfddbd4496628daa6. Doi: $10.1016 /$ S0886-3350(01)00925-7.

ANDREW, S.E. et al. Density of corneal endothelial cells and corneal thickness in eyes of euthanatized horses. American Journal of Veterinary Research, v.62, n.4, p.479-482, 2001. Disponível em: http://avmajournals.avma.org/doi/abs/10.2460/ ajvr.2001.62.479. Doi: 10.2460/ajvr.2001.62.479.

COLLIN, S.P.; COLLIN, H.B. A comparative study of the corneal endothelium in vertebrates. Clinical and Experimental Optometry, v.81, p.245-254, 1998.
DOUGHTY, M.J. Toward a quantitative analysis of corneal endothelial cell morphology: A review of techniques and their application. Optometry and Vision Sciense, v.66, n.9, p.626-646, 1989.

GALLAGHER, B.C. Primary cilia of the corneal endothelium. American Journal of Anatomy, v.159, n.4, p.475-484, 1980. Disponível em: http://www3.interscience.wiley.com/journal/ 109890069/abstract?CRETRY=1\&SRETRY $=0$. Doi: $10.1002 /$ aja. 1001590410 .

GWIN, L. et al. Decrease in canine corneal endothelial cell density an increase in corneal thickness as function of age. Investigative Ophthalmology \& Visual Science, v.22, n.22, p.267-271, 1982.

PIGATTO, J.A.T. et al. Morphometric analysis of the corneal endothelium of Yacare caiman (Caiman yacare) using scanning electron microscopy. Veterinary Ophthalmology, v.7, n.3, p. 205-208, 2004. Disponível em: http://www3.interscience.wiley.com/journal/118811881/ abstract. Doi: 10.1111/j.1463-5224.2004.04025.x.

PIGATTO, J.A.T. et al. Morphometric analysis of the corneal endothelium of rabbits using scanning electron microscopy. Acta Scientiae Veterinariae, v.33, n.1, p.41-45, 2005a.

PIGATTO, J.A.T. et al. Corneal endothelium of the Magellanic penguin (Spheniscus Magellanicus) by scanning electron 
microscopy. Journal of Zoo and Wildlife Medicine, v.36, n.5, p.702-705, 2005b.

PIGATTO, J.A.T. et al. Density of corneal endothelial cells in eyes of dogs using specular microscopy. Brazilian Journal of Veterinary Research and Animal Science, v.43, n.4, p.476-480, 2006

RODRIGUES, G.N. et al. Corneal endothelial cell morphology of normal dogs in different ages. Veterinary Ophthalmology, v.9, n.2, p.101-107, 2006. Disponível em: http:// www3.interscience.wiley.com/journal/118599174/abstract. Doi: $10.1111 /$ j.1463-5224.2006.00427.x.
SVEDBERGH, B., BILL, A. Scanning electron microscopic studies of the corneal endothelium in man and monkeys. Acta Ophthalmologica, v.50, p.321-335, 1972.

TUFT, S.J.; COSTER, D.J. The corneal endothelium. Eye, v.4, p.389-424, 1990

VIRTANEN, J. et al. The effect of fixation on corneal endothelial cell dimensions and morphology in scanning electron microscopy. Acta Ophthalmologica, v.62, n.4, p.577-585, 1984 .

YEE, R. et al. Specular microscopy of vertebrae corneal endothelium: a comparative study. Experimental Eye Research, v.44, n.55, p.703-714, 1987 